JPE (Jurnal Pendidikan Edutama) Vol. 6 No. 1 Januari 2019

P-ISSN : 2339-2258 (Print) E-ISSN: 2548-821X (Online)

http://ejurnal.ikippgribojonegoro.ac.id/index.php/JPE

\title{
PENANAMAN NILAI-NILAI KEMUHAMMADIYAHAN BERBASIS WAWASAN KEBANGSAAN PADA MAHASISWA PROGRAM STUDI PPKN UNIVERSITAS MUHAMMADIYAH PONOROGO
}

\author{
Prihma Sinta Utami ${ }^{1}$ \\ Program Studi PPKn, FKIP Unmuh Ponorogo \\ prihmasinta@gmail.com \\ Hadi Cahyono ${ }^{2}$ \\ Program Studi PPKn, FKIP Unmuh Ponorogo \\ email: hadicahyono0@gmail.com
}

\begin{abstract}
This article is the result of research conducted to know about the cultivation of values kemuhammadiyahan based on national insight on students study program and know the supporting and inhibiting factors of planting kemuhammadiyahan value based on national insight. The method used in this research is qualitative descriptive method with data collection techniques through interview and documentation activities. The results of this study indicate that: 1) The cultivation of the values of kemuhamamdiyahan based on national insight has been implemented by the students in daily activities both in the learning and field activities, but there is no specific method or strategy in the learning that integrates the two things; 2) Supporting factors for planting the value of kemuhamamdiyahan based on national insight because the curriculum study program that has been referring to the vision and mission of the university to print the students superior and Islamic so that it can be integrated in the form of RPS lecturers; 3) Factors inhibiting the planting of the value of kemuhamamdiyahan based on national insight because of the fanatical ideology of a particular Islamic religion outside the movement of muhamamdiyah on the student study program.
\end{abstract}

Keywords: Kemuhammadiyahan Values, National Insight, PPKn.

Abstrak:Tujuan dari penulisan artikel hasil penelitianini adalah untuk mengetahui: 1) penanaman nilai-nilai kemuhammadiyahan berbasis wawasan kebangsaan pada mahasiswa prodi PPKn; 2) faktor pendukung dan penghambat penanaman nilai kemuhammadiyahan berbasis wawasan kebangsaan. Metode yang digunakan dalam penelitian ini adalah metode penelitian kualitatif dengan pendekatan study fenomenologis. Teknik pengumpulan data melalui kegiatan wawancara dan dokumentasi. Hasil dari penelitian ini menunjukkan bahwa: 1) Penanaman nilai-nilai kemuhamamdiyahan berbasis wawasan kebangsaan sudah dilaksanakan mahasiswa dalam kegiatan sehari-hari baik dalam pembelajaran ataupun kegiatan lapangan, namun belum ada metode atau strategi khusus dalam pembelajaran yang mengintegrasikan kedua hal tersebut; 2) Faktor pendukung penanaman nilai kemuhamamdiyahan berbasis wawasan kebangsaan karena kurikulum prodi PPKn yang sudah mengacu pada visi dan misi universitas untuk mencetak mahasiswa unggul dan islami sehingga dapat diintegrasikan dalam wujud RPS dosen; 3) Faktor penghambat penanaman nilai kemuhamamdiyahan berbasis wawasan kebangsaan karena adanya paham-paham fanatik agama islam tertentu diluar gerakan muhamamdiyah pada mahasiswa prodi PPKn.

Kata kunci: Nilai-Nilai Kemuhammadiyahan, Wawasan Kebangsaan, PPKn. 


\section{PENDAHULUAN}

Meninjau kembali dari sejarah panjang perjuangan bangsa Indonesia, terbentuknya negara Indonesia tidak dapat lepas dari adanya Pancasila. Melihat proses perumusan Pancasila sendiri secara jelas terlihat para pendiri bangsa mengatakan bahwa antara agama dan negara merupakan dua hal yang tidak dapat dipisahkan namun menjadi dua mata uang yang saling melengkapi satu dengan yang lain. Indonesia tidak dapat dikatakan sebagai negara Islam, namun juga bukan merupakan negara sekuler yang memisahkan antara agama dan negara. Hal ini menunjukkan bahwa negara Indonesia pada dasarnya adalah negara kebangsaan yang menjunjung tinggi antara peran negara dan agama dalam satu konsep kesatuan yang beriringan.

Masyarakat Indonesia yang sebagian besar didominasi oleh masyarakat beragama Islam sangat memberikan pengaruh bagi kemajuan dan pertahanan wawasan kebangsaan. Muhammadiyah hadir sebagai gerakan Islam yang mengemban misi dakwah dan tajdid di tengah lintasan zaman yang penuh gelora. Seperti dijelaskan dalam keputusan muktamar satu abad Muhammadiyah, pada proses perjalanannya dari abad kesatu dan kedua Muhammadiyah mengedepankan pandangan tentang wawasan kebangsaan dan kemanusiaan universal sebagai komitmen yang menyatu dalam gerakannya. Konsep masyarakat Islam yang diharapkan oleh Muhamamdiyah mempunyai kesamaan dengan karakter masyarakat madani (civil society). Pada masyarakat Islam sebagai masyarakat madani selalu menjunjung kemajukan agama dan selalu memihak kepada kepentingan seluruh elemen masyarakat. (Satu \& Muhammadiyah, 2010: 9-10). Hal tersebut menjadi landasan dasar bahwa Muhammadiyah mampu untuk menjadi salah satu jembatan dalam perwujudan pertahan wawasan kebangsaan Indonesia.

Wawasan kebangsaan merupakan suatu cara memandang tentang jati diri bangsa dan lingkunggannya, esensinya ialah bagaimana bangsa Indonesia mampu memanfaatkan berbagai kondisi yang ada baik dari segi geografis, kondisi sosial, serta sejarah dalam mencapai suatu tujuan nasional (Sunarso, 2006: 165). Wawasan kebangsaan sendiri lahir lantaran adanya proses perjuangan bangsa Indonesia ketika melawan penjajahan dengan melalui lika liku dan cerita yang melibatkan berbagai komponen dalam masyarakat Indonesia itu sendiri. Berbagai komponen dalam masyarakat itulah yang menunjukkan bahwa bangsa Indonesia bukan hanya terdiri dari satu suku, budaya maupun agama namun terdiri dari berbagai komponen meliputi dari sabang sampai merauke. Hal inilah yang seharusnya menjadi perhatian terus menerus untuk dapat mewujudkan persatuan dan kesatuan dengan pemahaman konsep wawasan kebangsaan.

Pemahaman konsep wawasan kebangsaan perlu ditanamkan pada setiap generasi penerus melalui berbagai media. Pemuda memegang peranan yang penting dalam proses memajukan bangsa melalui berbagai kiprahnya baik dalam bidang organisasi, agama, pendidikan maupun dalam kegiatan sosial masyarakat yang lainnya. Namun pada kenyataannya saat ini pemahaman wawasan kebangsaan belum sepenuhnya dipahami dan dihayati oleh masyarakat secara umum bahkan bagi para pemimpin negara yang seharusnya menjadi role model bagi rakyat. Terlebih saat ini yang marak terjadi kembali adalah terkait kasus- kasus SARA yang mulai bermunculan kembali.

Selain kasus SARA yang santer diberitakan kembali saat ini adalah terkait kasus korupsi yang terus merajalela di 
bangsa Indonesia saat ini. Seperti yang dilansir dari media kompas yang memberitakan tentang dugaan KPK terhadap perbuatan melawan hukum serta penyalahgunaan kekuasaan atau wewenang yang bermpak pada kerugian negara terkait adanya proyek KTP elektronik ( dilansir dari https://indeks.kompas.com/topikpilihan/list 13058/dugaan-korupsi-proyek-e-ktp/desc/3 diakses pada tanggal 10 September 2018). Kasus tersebut menunjukkan bahwa masih rendahnya kualitas moral dan keimanan seseorang. Apabila seseorang mempunyai keimanan, maka kasus-kasus seperti ini dapat diminimalisir di bangsa ini. Hal inilah yang seharusnya menjadi penguat mengapa perlu nilai-nilai keagamaan yang menyeluruh pada setiap komponen masyarakat, namun pada kenyataan belum sepenuhnya hal ini dapat terwujud.

Berkenaan dengan hal tersebut Muhammadiyah sebagai salah satu gerakan Islam mengedepankan nilai-nilai yang diharapkan mampu memperkuat karakter seseorang dan memperkuat nilainilai perdamaian. Seperti yang disampaikan oleh Nashir (2012: 45) bahwa Muhammadiyah wajib memelihara sifatsifat seperti (1) beramal dan berjuang untuk perdamaian dan kesejahteraan; (2) memperbanyak kawan dan mengamalkan ukhuwah Islamiyah; (3) lapang dada, luas pandangan dengan memegang ajaran Islam; (4) bersifat keagamaan dan kemasyarakatan; (5) mengindahkan segala hukum; (6) amar ma'ruf nahi munkar dan menjadi teladan; (7) aktif dalam perkembangan masyarakat; (8) kerjasama dengan golongan Islam manapun, (9) bekerjasama dalam membangun negara; (10) bersifat adil.

Selanjutnya Nashir (2012: 123-151) juga membagi nilai-nilai kemuhammadiyahan yang dapat dijadikan pedoman bagi pengintegrasian wawasan kebangsaan masyarakat Indonesia yang tergambar dari pedoman hidup islami warga Muhammadiyah sebagai berikut: 1) kehidupan pribadi; 2) kehidupan dalam keluarga; 3) kehidupan bermasyarakat; 4) kehidupan mengembangkan profesi; 5) kehidupan dalam berbangsa dan bernegara; 6) kehidupan dalam melestarikan lingkungan; 7) kehidupan mengembangkan IPTEK; 8) kehidupan dalam seni dan budaya.

Kembali lagi pada keputusan muktamar satu abad Muhammadiyah yang mengedepankan pemikiran bahwa wawasan kebangsaan serta konsep kemanusiaan universal sebagai suatu komitmen yang terus menyatu dalam gerakannya, hal ini perlu mendapat dukungan dan apresiasi dari berbagai pihak. Kampus dibawah payung persyarikatan Muhammadiyah dapat menjadi salah satu jembatan untuk mengintegrasikan antara nilai-nilai Islam kemuhammadiyahan dan tujuan nasional bangsa Indonesia tersebut. Salah satu penekanan dapat dilakukan kepada mahasiswa-mahasiswa dengan berbasis prodi kewarganegaraan. Hal ini dilakukan sebagai persiapan bagi mahasiswa untuk dapat meneruskan pada generasi kedepannya tentang wawasan kebangsaan yang tidak menghilangkan nilai- nilai keislaman khususnya nilai kemuhammadiyahan.

Program Studi Pendidikan

Pancasila dan Kewarganegaraan (PPKn) merupakan salah satu prodi di Fakultas Keguruan dan Ilmu Pendidikan (FKIP) Universitas Muhammadiyah Ponorogo. Prodi PPKn adalah prodi yang berkenaan langsung tentang pendidikan kewarganegaraan sebagai salah satu kajian utama dalam mata kuliahnya. 
Selain pendidikan kewarganegaraan, di prodi tersebut juga diperkuat dengan kajian mata kuliah pendidikan pancasila, pendidikan demokrasi, study masyarakat Indonesia, pendidikan ilmu sosial, pendidikan ilmu politik serta berbagai mata kuliah yang mendukung pada kompetensi lulusan untuk menjadi calon pendidik kewaragnegaraan yang baik. Tidak terlewatkan dan sudah menjadi mata kuliah wajib yang perlu ditempuh mahasiswa prodi PPKn tersebut adalah mata kuliah kemuhammadiyahan. Berkenaan dengan hal tersebut diharapkan mahasiswa mampu mempunyai dua kekuatan pendukung dalam mencapai tujuan nasional bangsa Indonesia yaitu melalui kemampuannya dalam penerapan konsep kewarganegaraan dan nilai kemuhammadiyahan. Oleh karena itu, peneliti tertarik untuk melakukan penelitian dengan judul "penanaman nilai-nilai kemuhammadiyahan berbasis wawasan kebangsaan pada mahasiswa Program Studi PPKn Universitas Muhammadiyah Ponorogo"

\section{METODE PENELITIAN}

Penelitian ini merupakan penelitian kualitatif dengan pendekatan study fenomenologis. Sumber data primer yang digunakan dalam penelitian ini adalah mahasiswa Prodi PPKn Universitas Muhammadiyah Ponorogo dan kaprodi PPKn. Sumber data sekunder dalam penelitian ini adalah daftar jumlah mahasiswa yang telah mengikuti mata kuliah Al Islam Kemuhammadiyahan (AIK), RPS dosen, daftar mahasiswa yang telah mengikuti mata kuliah kewarganegaraan, kurikulum prodi PPKn.

Teknik pengumpulan data dalam penelitian ini adalah melalui observasi, wawancara dan dokumentasi. Observasi dilakukan peneliti untuk mengamati persitiwa langsung yang terjadi di lapangan. Wawancara dilakukan dengan menggunakan kuesioner terbuka dengan daftar pertanyaan yang telah disusun secara sistematis untuk mendapat jawaban secara mendalam dan detail dari informan. Studi dokumentasi yang dilakukan oleh peneliti antara lain dengan cara mencatat semua hasil wawancara dari informan, membuat catatan lapangan serta foto-foto terkait.

Teknik analisis data yang digunakan dalam penelitian ini adalah dengan menggunakan analisis data sesuai dengan pendapat Sugiyono (2016) dengan tahapan sebagai berikut: 1) Reduksi Data, merupakan proses pemilihan, pemisahan, penyederhanaan data kasar dari informan yang di dapat di lapangan saat penelitian; 2) Penyajian Data, untuk menyajikan data dari hasil wawancara ke dalam bentuk uraian disertai dokumen pendukung; 3) Penarikan Kesimpulan, merupakan proses memverifikasi dari hasil penelitian berlangsung atau selama proses pengumpulan data.

\section{HASIL DAN PEMBAHASAN \\ Hasil}

Temuan hasil penelitian di lapangan dapat dijelaskan sebagai berikut:

1. Secara garis besar dari hasil wawancara yang telah dilakukan reduksi dan analisis data diperoleh hasil bahwasannya nilai-nilai kemuhammadiyahan sudah diterapkan pada kegiatan mahasiswa prodi PPKn yang ditunrukan berdasarkan pedoman visi dan misi prodi PPKn yang selaras dengan visi misi Universitas. 
2. Konsep wawasan kebangsaan sudah include dalam kurikulum dan RPS dosen prodi PPKn.

3. Penerapan nilai-nilai kemuhammadiyahan berbasis wawasan kebangsaan sudah dilaksanakan dalam kegiatan mahasiswa prodi PPKn namun belum terintegrasi dalam perkuliahan dalam bentuk metode khusus integrasi keduanya.

4. Faktor pendukung penanaman nilai kemuhammadiyahan berbasis wawasan kebangsaan pada mahasiswa prodi PPKn karena adanya visi dan misi yang sama antara prodi PPKn dengan Universitas sehingga mempermudah untuk diturunkan dalam kurikulum dan RPS dosen.

5. Faktor penghambat penanaman nilai kemuhammadiyahan berbasis wawasan kebangsaan pada mahasiswa prodi PPKn karena banyaknya paham-paham fanatik agama tertentu yang melatarbelakangi mahasiswa PPKn

\section{Pembahasan}

Berikut pembahasan dari hasil penelitian yang telah diperoleh:

\section{Penerapan}

Nilai-Nilai

\section{Kemuhammadiyahan Pada Prodi PPKn}

Sejak berdiri pada tahun 1912 Muhammadiyah menegaskan bahwa merupakan gerakan Islam yang akan berjuang untuk menyebarluaskan serta memajukan ajaran Islam di Indonesia. Hal ini diilhami oleh firman Allah SWT dalam surat Ali Imron 104 (Satu \& Muhammadiyah, 2010: 2). Misi yang diusung oleh gerakan Muhammadiyah tersebut dikenal dengan dengan gerakan dakwah dan tajdid. Pendapat lain disampaikan Jinan (2015: 271) yang mengemukakan bahwa "sejak kelahirannya Muhammadiyah memposisikan dan memerankan diri sebagai gerakan Islam untuk menyebarluaskan dan mamajukan halihwal agama Islam di Indonesia. Kyai Dahlan dengan Muhammadiyah yang didirikannya bahkan dikategorikan sebagai bagian dari matarantai gerakan Islam pembaruan di dunia Islam".

Berkenaan dengan tujuan gerakan Muhamamdiyah tersebut maka lembagalembaga di bawah naungan Muhammadiyah pun juga harus menerapkan hal serupa, tidak lain juga di Perguruan Tinggi Muhammadiyah salah satunya di Universitas Muhammadiyah Ponorogo. Sejalan dengan visi yang diusung universitas yaitu "Menjadi universitas yang unggul dalam penguasaan ilmu pengetahuan, teknologi, dan seni berdasarkan nilai-nilai Islami”.

Berangkat dari visi dan misi universitas tersebut, maka diturunkan pula visi dan misi ke fakultas maupun prodi yang berada dalam naungan Universitas Muhammadiyah Ponorogo. Hal ini juga terlihat dari visi dan misi yang diusung oleh prodi PPKn yang mengacu pada visi misi universitas yaitu "menjadi program studi unggulan ditingkat nasional dalam mencetak para pendidik dan praktisi hukum, politik, sosial dan pemerintahan yang profesional, keislaman, berilmu, dan berwawasan global".

Penerapan nilai-nilai kemuhammadiyahan pada prodi PPKn juga terlihat dari kurikulum yang dibentuk oleh prodi. Pada kurikulum prodi PPKn itu sendiri sudah ada muatan Mata Kuliah Universitas (MWU) yang didalamnya sudah include mata kuliah tentang $\mathrm{Al}$ Islam Kemuhammadiyahan (AIK) yang meliputi agama islam, islam dan ilmu pengetahuan, kemuhamamdiyahan, serta akhlaq dan muamalah. Keempat mata kuliah tersebut di prodi PPKn diberikan kepada mahasiswa pada semester satu sampai semester empat. Dari hal tersebut dapat disimpulkan bahwa mahasiswa prodi 
PPKn secara umum sudah diberikan bekal pengetahuan tentang nilai-nilai kemuhammadiyahan melalui mata kuliah yang diikutinya.

Selain dari segi pembelajaran, penerapan nilai-nilai kemuhammadiyahan juga terlihat dari berbagai kegiatan yang dilakukan oleh mahasiswa prodi PPKn. Salah satu hal yang menggambarkan pernyataan tersebut adalah ada beberapa mahasiswa prodi PPKn yang tergabung dalam organisasi kampus yaitu Ikatan Mahasiswa Muhammadiyah (IMM).

Dari hasil yang diperoleh di lapangan, dari beberapa sumber informan memberikan respon positif dari pemberian mata kuliah Al Islam Kemuhammadiyahan (AIK) atau nilai-nilai kemuhammadiyahan. Sekitar $70 \%$ responden mengatakan dengan adanya mata kuliah tentang AIK mereka lebih mengetahui bacaan ibadah dengan benar. Selanjutnya mereka mengatakan lebih memahami tentang agama islam khususnya gerakan dibawah muhammadiyah. Selain itu, dari infroman juga diperoleh hasil bahwasannya mereka lebih mengetahui tentang pergerakanpergerakan islam di Indonesia beragam, salah satunya adanya gerakan Muhammadiyah.

\section{Penerapan Konsep Wawasan Kebangsaan Pada Prodi PPKn}

Setiap negara atau bangsa mempunyai pandangan hidup dan cita- cita bagi bangsanya sendiri-sendiri. Termasuk bangsa Indonesia tentunya mempunyai tujuan nasional yang harus diwujudkan melalui visi dan misi bangsa tersebut. Kemerdekaan yang diraih bangsa Indonesia bukanlah akhir dari tujuan nasional, namun merupakan suatu alat untuk dapat mewujudkan bangsa Indonesia yang merdeka, berdaulat, bersatu, adil, dan makmur. Oleh karena itu bangsa Indonesia memerlukan suatu pandangan tentang wawasan kebangsaan bangsa Indonesia sendiri untuk mempertahankan ketahanan negara dan jati dirinya.

Wawasan kebangsaan secara umum dijelaskan oleh Kaelan (2002: 33-34) berarti bahwa suatu cara pandang bangsa Indonesia tentang diri dan lingkungannya yang berdasarkan pada Pancasila dan UUD 1945 sesuai dengan geografi wilayah Nusantara yang menjiwai kehidupan bangsa untuk mencapai cita-cita nasionalnya. Hal ini berarti bahwa wawasan nusantara juga dikatakan sebagai cara pandangan untuk mengajarkan bagaimana pentingnya membina persatuan dan kesatuan dalam mencapai tujuan dan cita-citanya.

Mengacu pada pentingnya pemahaman wawasan kebangsaan bagi warga negara Indonesia, prodi PPKn sebagai prodi yang mempersiapkan calon pendidik yang mempunyai kecapakan warga negara yang baik maka perlu pemahaman mendalam tentang konsep tersebut. Hal ini juga selaras dengan visi dan misi prodi PPKn Unmuh Ponorogo. Selanjutnya dari hasil yang diperoleh di lapangan wujud implementasi visi dan misi prodi tersebut diturunkan pada kurikulum prodi dan RPS dosen.

Pada hasil di lapangan mahasiswa prodi PPKn Unmuh Ponorogo wajib mendapatkan mata kuliah kewarganegaraan. Mata kuliah kewarganegaraan sendiri menjadi Mata Kuliah Wajib Universitas (MKWU). Berdasarkan hasil wawancara dengan kaprodi dan beberapa dosen prodi PPKn mata kuliah ini sangat penting diberikan kepada mahasiswa khusunya mahasiswa PPKn. Pertama untuk, membentuk watak dan karakter warga negara yang berlandaskan akan nila-nilai pancasila. Kedua. Membangun wawasan dan kesadaran kebangsaan, cinta tanah air, demokrasi , penghargaan atas keragamaan 
dan partisipasinya membangun bangsa berdasar Pancasila. Ketiga, mewujudnya warga negara yang cerdas, trampil dan berkarakter sehingga dapat diandalkan guna membangun bangsa dan negara berdasar Pancasila dan UUD 1945 sesuai dengan bidang keilmuan dan profesinya. Keempat, sebagai proses penanaman kecakapan warga negara Abad ke-21.

Melihat dari kurikulum prodi PPKn secara garis besar mata kuliah diarahkan pada konsep wawasan kebangsaan, seperti mata kuliah kewarganegaraan, pendidikan pancasila, idiologi pancasila, study masyarakat Indonesia, sistem demokrasi Indonesia, dll. Konsep ini juga diturunkan pada RPS dosen-dosen PPKn. RPS dosen PPKn mengedepankan pada konsep wawasan kebangsaan, salah satunya dengan selalu menyisipkan nilai-nilai karakter kebangsaan dalam RPS.

Urgensi pemahaman tentang wawasan kebangsaan juga dirasakan bagi mahasiswa prodi PPKn. Dari hasil yang diperoleh mahasiswa merasa sangat penting memperoleh pengetahuan tentang kewarganegaraan dan wawasan kebangsaan untuk meningkatkan rasa nasionalisme tiap orang agar sadar akan keamanan dan kesejahteraan negara.

\section{Penerapan}

Nilai-Nilai

Kemuhammadiyahan Berbasis Wawasan Kebangsaan Pada Mahasiswa Prodi PPKn Universitas Muhammadiyah

\section{Ponorogo}

Dilihat dalam konteks kebangsaan

Muhammadiyah banyak berkiprah dan menorehkan peninggalan yang berpengaruh bagi bangsa Indonesia. Muhammadiyah dikenal sebagai pembawa panji pembaruan dan kemajuan. Tokoh sentral pergerakan Indonesia, Proklamator dan Presiden Pertama Republik Indonesia, Soekarno atau Bung Karno bukan sosok yang asing lagi bagi Muhammadiyah. Tokoh ini tertarik pada Muhammadiyah karena paham kemajuannya tentang Islam (Nashir, 2016:9).

Seperti yang dikutip pada pernyataan pikiran Muhammadiyah abad kedua dalam Satu \& Muhammadiyah (2010: 2) yang mengatakan bahwa pada era kolonial Muhammadiyah berperan dalam pergerakan kebangkitan kebangsaan menuju kemerdekaan Indonesia. Selain itu jelas masih teringat dalam catatan sejarah pada awal kemerdekaan Indonesia dimana Muhammadiyah mempunyai peran dalam kunci penentuan dasar negara. Tokoh Muhammadiyah di masa lalu mempunyai sumbangsih pada penentuan dasar negara, terutama $\mathrm{Ki}$ Bagus yang merupakan kunci terakhir lahirnya kesepakatan Pancasila sebagai Dasar Negara RI. Seperti yang dikutip dalam Hidayat (2016: 13) yang menyatakan bahwa ketika perumusan Pancasila pada rumusan sila I yang dikenal saat ini yaitu Ketuhanan Yang Maha Esa, frasa "Yang Maha Esa" merupakan usulan dari $\mathrm{Ki}$ Bagus sebagai pengganti tujuh kata "dengan kewajiban menjalankan syariat Islam bagi pemeluk-pemeluknya". Makna yang diusulkan oleh Ki Bagus tersebut bahwa Ketuhanan Yang Maha Esa bermakna tauhid (tauhidullah) bagi umat Islam.

Dari beberapa acuan diatas perlu adanya integrasi antara nilai-nilai Muhammadiyah dengan konsep wawasan kebangsaan yang harus dipahami oleh mahasiswa khususnya mahasiswa PPKn dibawah naungan gerakan muhamamdiyah. Berikut pemaparan hasil yang diperoleh dari beberapa komponen nilai muhamamdiyah berbasis wawasan kebangsaan yang terjadi di prodi PPKn FKIP Universitas Muhammadiyah Ponorogo. 
1) Nilai Kemuhammadiyahan Pada Kehidupan Pribadi

Nasir (2012:

menjelaskan bahwa dalam kehidupan pribadi Muhamamdiyah harus mampu menjadi pribadi yang mampu menceminkan cara pikir islami yang berorientasi pada prinsip hablumminallah dan hablumminannas. Dari hasil yang diperoleh pada wawancara dengan mahasiswa PPKn bahwasannya prinsip ini sudah dilakukan oleh masing-masing mahasiswa, hal ini dilihat dari aktifitas yang dilakukan di kampus sehari-hari. Salah satu aktifitas tersebut tergambar ketika proses sebelum dan sesudah pelaksanaan perkuliahan yang selalu diawali dan diakhiri dengan berdoa atau membaca alquran bersama.

Dari beberapa wawancara dosen juga menjelaskan bahwa dalam prinsip hablumminallah mahasiswa PPKn selalu dikuatkan dengan konsep-konsep nilai muhammadiyah salah satunya dengan pembiasaan-pembiasaan di dalam kelas. Pengimplementasian nilainilai ini diterapkan dari dalam bentuk proses learning to know, learning to do, learning to be, dan learning to live together in peace pada setiap mata kuliah yang diajarkan.

Hal lain yang dijumpai dari hasil wawancara dosen pada prinsip hablumminallah yaitu pembiasaan untuk melakukan ibadah tepat pada waktunya. Hal ini sudah menjadi peraturan di universitas dan diturunkan pula ke fakultas serta prodi bahwasannya ketika mendengar adzan maka semua kegiatan perkuliahan atau aktifitas lain ditinggalkan sejenak dan melakukan sholat berjamaah di masjid.

Prinsip hablumminannas pada prodi PPKn tergambar pada proses pembelajaran di kelas. Hal ini tergambar dari adanya sikap saling toleransi dan menghargai sesama mahasiswa ketika kegiatan diskusi di kelas. Antar mahasiswa saling menghargai pendapat orang lain ketika proses diskusi ataupun presentasi. Selain itu hal ini juga tergambar dari kemampuan mahasiswa dalam bekerjasama dengan tim baik dalam kegiatan perkuliahan ataupun dalam kegiatan HMPS PPKn.

Konsep hablumminallah dan hablumminannas yang kedua juga tergambar dari tindakan untuk menjauhkan diri dari sikap tidak jujur salah satunya yaitu tindakan korupsi dan kolusi. Sebagai warga Muhamamdiyah harus mampu menjaga aqidah dengan menjadi pribadi yang selalu menjauhkan diri dari perbuatan korupsi dan kolusi yang mampu membawa pada kerugian bagi hak publik, Nashir (2012: 123-151).

Hal tersebut juga dipahami oleh mahasiswa PPKn dengan memandang pada dua sudut pandang. Dalam kaca mata Islam dapat disimpulkan bahwa tindakan korupsi merupakan perbuatan melanggar ajaran agama islam yang mengambil bukan haknya serta perlu mendapat sanksi yang tegas. Pada pandangan warga negara pelaku korupsi dan kolusi perlu mendapatkan sanksi hukum yang tegas karena hal ini jelas melanggar konstitusi.

Secara garis besar konsep hablumminallah dan hablumminannas sudah dilaksanakan mahasiswa dalam kegiatan perkuliahan sehari-hari, hanya saja untuk menerapkan konsep ini belum ada strategi atau metode khusus yang dapat dilakukan oleh dosen agar dapat mengintegrasikannya dalam setiap perkuliahan.

2) Nilai Kemuhammadiyahan Pada Kehidupan Keluarga 
Nashir (2012: 123-151) mengatakan bahwa dalam konsep kehidupan keluarga pada nilai-nilai muhammadiyah, setiap keluarga muhamamdiyah harus mampu memiliki kepedulian sosial yang ihsan, islah, dan ma'ruf dengan lingkungan masyarakat sekitar. Keluarga muhammadiyah harus mampu menciptakan suasana keluarga yang positif sesuai dengan ajaran agama islam.

Kepedulian sosial juga tergambar pada mahasiswa prodi PPKn. Hal ini bertujuan untuk rasa saling perduli membantu satu sama lain dalam setiap kegiatan urusan perkuliahan. Dalam kegiatan kepedulian sosial di masyarakat terwujud dari adanya tindakan kemsyarakatan salah satunya kegiatan baksos yang bersamaan dengan HMPS PPKn. Selain itu mahasiswa banyak yang terlibat dalam kegiatan penentuan kebijakan permasalahan dalam masyarakat.

3) Nilai Kemuhammadiyahan Pada Kehidupan Bermasyarakat

Konsep hubungan sosial warga muhammadiyah harus mencakup pada beberapa aspek yaitu sebagai individu, keluarga, maupun dalam posisi sebagai jamaah (warga) dan jam"iyah (organisasi), Nashir (2012: 123-151).

$$
\text { Pada prodi PPKn Unmuh }
$$

Ponorogo mahasiswanya sangat

beragam atau dapat dikatakan bersifat multikultural. Hal ini dapat dikatakan demikian karena rata-rata mahasiswa di setiap angkatan berasal dari berbagai wilayah di Indonesia. Keadaan demikian rentan dengan adanya banyak perbedaan ragam budaya, bahasa maupun idiologi sehingga rentan pula dengan adanya permasalahan. Namun pada kenyataannya mahasiswa PPKn mampu untuk menjaga adanya keberagaman tersebut dan mampu

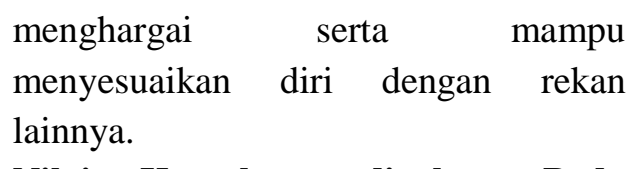

4) Nilai Kemuhammadiyahan Pada Kehidupan Mengembangkan Profesi

Warga muhammadiyah yang sudah menentukan serta menjalankan profesi sesuai dengan bidangnya masing-masing selalu ditekankan untuk menjunjung nilai kehalalan dan kebaikan serta amanah dalam menjalan kan tugas (Nashir, 2012:123-151). Hal tersebut tergambar dari tindakan nyata untuk menghindari adanya korupsi ataupun kolusi.

Sebagai mahasiswa PPKn yang tidak asing lagi dengan istilah-istilah politik khusunya dengan istilah korupsi, hal ini menjadi prinsip dalam tindakan sehari-hari. Prinsip ini diperkuat dengan adanya mata kuliah tentang pendidikan anti korupsi pada prodi PPKn Unmuh Ponorogo. Implementasi mata kuliah ini dapat berupa study kasus di lapangan terkait dengan tindakan korupsi dan memberikan hasil solusi dari kasus tersebut.

5) Nilai Kemuhammadiyahan Pada Kehidupan Berbangsa dan Bernegara

Pada konsep nilai

muhamamdiyah berikut, sebagai warga muhammadiyah diharuskan untuk tidak bersikap masa bodoh atau apatis dalam setiap kegiatan berpolitik dengan tujuan membangun islam (Nasir, 2012: 123151). Lebih lanjut prinsip berpolitik Muhammadiyah sendiri dimaksudkan untuk mewujudkan masyarakat islam dengan funsi amar ma'ruf dan nahi munkar.

Ada beberapa hal yang dijumpai pada penerapan nilai tersebut pada mahasiswa prodi PPKn. Nilai ini belum sepenuhnya dapat dijalankan pada semua mahasiswa. Banyak dijumpai di 
lapangan bahwasannya latar belakang mahasiswa tidak semuanya dari gerakan muhamamdiyah, melainkan dari organisasi islam lainnya. Sehingga konsep berpolitik yang dipegang hanya mengacu pada pemahaman konseptual terkait idiologi politik itu sendiri. Hal ini dikatakan yang menjadikan sulit untuk mengembangkan konsep politik dengan berlandaskan wawasan nilai islam kemuhamamdiyahan.

Pada kenyataan di lapangan mahasiswa prodi PPKn banyak yang berkecimpung dalam dunia politik. Beberapa mahasiswa dijumpai menjadi anggota BPD di daerahnya masingmasing. Selain itu juga banyak dijumpai mahasiswa yang terlibat andil dalam kegiatan pilkada atau pemilu, sehingga menunjukkan bahwasannya mahasiswa PPKn sudah berkontribusi bagi masyarakat umum.

Kelemahan pada penerapan nilainilai ini dikatakan pada konsep yang berbeda dalam bingkai organisasi Islam masing-masing mahasiswa. Ada beberapa mahasiswa yang menjadi pengurus gerakan organisasi islam, bahkan banyak yang menjadi pengajar di pondok-pondok pesantren di kota Ponorogo. Namun, kembali lagi kelemahannya terletak pada perbedaan konsep nilai-nilai islam yang akan disebarkan.

Dari penjelasan tentang penanaman nilai muhamamdiyah berbasis wawasan kebangsaan pada mahasiswa prodi PPKn tersebut dapat diambil benang merah bahwasannya secara garis besar penerapan keduanya sudah tergambar pada kegiatan mahasiswa. Namun secara khusus untuk menyampaikan metode atau strategi pengajaran berbasis dua komponen tersebut belum ada sampai saat ini. Sehingga diharapkan melalui penelitian ini ada rekontruksi kembali tentang mata kuliah dan penurunan RPS prodi PPKn khususnya.

Faktor-Faktor Pelaksanaan Nilai Kemuhamamdiyahan Berbasis Wawasan Kebangsaan Pada Prodi PPKn

Pada pelaksanaan penanaman nilainilai kemuhammadiyahan berbasis wawasan kebangsaan pada mahasiswa prodi PPKn Unmuh Ponorogo ada beberapa hal yang menjadi faktor pendukung dan penghambat pelaksanaan tersebut. Hal ini dilihat dari beberapa tindakan nyata yang sudah terjadi di lapangan.

Melihat pada visi dan misi prodi PPKn sudah selaras atau sejalan dengan visi dan misi Universitas, dimana samasama untuk mencetak mahasiswa yang unggul dan islami atau beriman (dalam lingkup prodi). Hal tersebut dapat menjadi salah satu faktor pendukung untuk mengembangkan prinsip-prinsip nilai muhamamdiyah dengan konsep wawasan kebangsaan.

Faktor pendukung lainnya dilihat dari kurikulum prodi PPKn yang tergambar dari mata kuliah dan RPS yang dimiliki oleh dosen. Pada kurikulum PPKn sudah ada mata kuliah tentang konsep nilai-nilai muhammadiyah. Selain itu pada kurikulum prodi PPKn konsep wawasan kebangsaan juga sudah diturunkan melalui mata kuliah dan RPS dosen. Namun untuk implementasi kedua hal tersebut yang mengintegrasikan antara nilai kemuhamamdiyahan dan konsep wawasan kebangsaan belum ada. Maka perlu adanya rekontruksi kembali atau pembuatan metode dan strategi pembelajaran baru yang mengintegrasikan keduanya.

Di samping adanya faktor pendukung untuk penerapan nilai-nilai muhamamdiyah yang berbasis wawasan 
kebangsaan tersebut, ada beberapa hal yang menjadi penghambat pelaksanaan keduanya. Dari hasil wawancara di lapangan, salah satu hal yang menjadi penghambat yaitu adanya paham-paham fanatik terhadap suatu agama oleh sebagian mahasiswa PPKn yang tidak semuanya dari muhamamdiyah. Selain itu hal lain yang menjadi penghambat karena belum adanya acuan khusus untuk dapat mengintegrasikan antara nilai muhamamdiyah dan konsep wawasan kebangsaan dalam pembelajaran PPKn.

\section{SIMPULAN}

Berdasarkan hasil penelitian yang sudah dilakukan, serta berdasarkan hasil analisis data yang sudah dilakukan maka dapat disimpulkan sebagai berikut:

1. Nilai-nilai kemuhammadiyahan sudah diterapkan dalam komponen pembelajaran maupun dalam kegiatankegiatan yang dilakukan di prodi PPKn FKIP Unmuh Ponorogo. Penerapan nilai-nilai kemuhammadiyahan pada prodi PPKn diturunkan dari visi-misi prodi PPKn yang menjadikan mahasiswa unggul dan islami selaras dengan visi misi universitas serta diturunkan pada kurikulum prodi.

2. Konsep wawasan kebangsaan sudah terlaksana dan dipahami oleh mahasiswa prodi PPKn karena sudah terangkum dalam aturan kurikulum prodi PPKn yang diturunkan pada mata kuliah dan RPS dosen yang mengedepankan konsep wawasan kebangsaan.

3. Penerapan nilai-nilai kemuhammadiyahan berbasis wawasan kebangsaan secara garis besar sudah dilakukan oleh mahasiswa dalam kehidupan sehari-hari, namun belum sepenuhnya include dalam setiap mata kuliah ataupun tergambar dalam bentuk metode pembelajaran khusus yang mengintegrasikan diantara keduanya sehingga perlu adanya rekontruksi kembali.

4. Faktor pendukung penanaman nilai kemuhammadiyahan berbasis wawasan kebangsaan pada mahasiswa prodi PPKn salah satunya adalah karena visi dan misi universitas ataupun prodi PPKn sudah sama sama untuk mencetak mahasiswa yang unggul dan islami/ beriman (prodi). Selain itu kurikulum prodi PPKn yang sudah mendukung konsep wawasan kebangsaan dapat diintegrasikan dengan nilai-nilai kemuhammadiyahan.

5. Faktor penghambat penanaman nilai kemuhammadiyahan berbasis wawasan kebangsaan pada mahasiswa prodi PPKn, secara garis besar mahasiswa PPKn tidak seluruhnya berasal dari Muhamamdiyah sehingga pahampaham fanatik agama tertentu masih menjadi kendala. Faktor lainnya karena belum adanya acuan untuk dapat mengintegrasikan antara nilai kemuhamamdiyahan dengan konsep wawasan kebangsaan.

\section{DAFTAR RUJUKAN}

Hidayat, S. (2016). Negara Pancasila sebagai Darul'Ahli wa al-Syahadah Wawasan dan Kontribusi Muhammadiyah Bagi NKRI. Jurnal Tajdida Vol.14, No.1.

Jinan, M. (2015). MUHAMMADIYAH STUDIES : TRANSFORMASI KAJIAN TENTANG GERAKAN ISLAM DI INDONESIA, 269-280.

Kaelan. 2002. Pendidikan Kewarganegaraan. Yogyakarta: Paradigma 
Nashir, H. (2012). MANHAJ GERAKAN MUHAMMADIYAH (Ideologi, Khittah, dan Langkah). Yogyakarta: GRAMASURYA

Nashir, Haedar. (2016).

MUHAMMADIYAH: GERAKAN MODERNISME ISLAM. Jurnal Tajdida Vol.14, No.1

Satu, M., \& Muhammadiyah, A. (2010). Pernyataan pikiran muhammadiyah abad kedua.

http://www.kontenberita.com/2016/10/09-

Merawat-Keragaman- KelompokPemuda-Suarakan-Pilkada-2017-

Bebas-Isu-SARA. html diakses pada tanggal (10 September 2016)

https://indeks.kompas.com/topikpilihan/list 13058/dugaan-korupsi-proyek-e-ktp/desc/3 html diakses pada tanggal (10 September 2018) 